\title{
Evaluation of pharmacological activities of methanol extract of Ixora cuneifolia leaves
}

\author{
Tamanna Binte Huq ${ }^{1}$, M. Sohanur Rahman², M. Akhlatun Nure, Md Solayman Hossain ${ }^{4}$, Abeer Sarwar', \\ Azharul Islam ${ }^{5}$ Munny Das ${ }^{1}$, Md Emdadul Haque ${ }^{5}$, Tasnia Malik', Md Wali Reza' ${ }^{1}$ Bikash Chandra Adhikary ${ }^{6}$, \\ Minhazur Rahman ${ }^{6}$, Taslima Begum ${ }^{6}$ and Mst Marium Begum ${ }^{7^{*}}$
}

\begin{abstract}
Background: In the current study in vitro antioxidant, thrombolytic and in vivo analgesic, anti-inflammatory, antidiarrheal activities of methanol extract of Ixora cuneifolia leaves (MEIL) were investigated.

Methods: The antioxidant activity was determined by using DPPH free radical scavenging method at doses 25, 50, 100, 200, 400 and $800 \mu \mathrm{g} / \mathrm{ml}$. Total phenolic content was determined at doses of 50, 100, 150, 200 and $250 \mu \mathrm{g} / \mathrm{ml}$. Whereas thrombolytic activity was determined by clot lysis method. The analgesic activity was conducted in Swiss albino mice at doses of 250 and $500 \mathrm{mg} / \mathrm{kg}$ body weight by hot plate method and acetic acid induced writhing method. Carrageenan induced rat paw edema method was used to evaluate anti-inflammatory activity. For antidiarrheal activity castor oil induced method was used at the same dose mentioned earlier.
\end{abstract}

Results: Initial phytochemical study revealed the presence of flavonoids, saponins, gums, terpenoids, steroids and reducing sugars. The extract possessed significant $(p<0.05-0.001)$ free radical scavenging properties (IC50 for DPPH scavenging activity is $57.6464 \mu \mathrm{g} / \mathrm{ml}$ and also contained marked amount of phenols $46.44 \pm 1.022 \mathrm{mg} / \mathrm{gm}$ (Gallic acid equivalents). In clot lysis activity the extract showed potent lysis capacity (48.41\%). In the hot plate method the extract produced a significant $(p<0.05)$ dose dependent reduction of thermally induced pain. The extract also showed significant $(p<0.001)$ inhibition of the total number of writhing produced in the acetic acid induced writhing method. Highest inhibition of writhing was $66 \%$ at dose of $500 \mathrm{mg} / \mathrm{kg}$ body weight. In carrageenan induced paw edema test the extract at doses 250 and $500 \mathrm{mg} / \mathrm{kg}$ produced significant $(p<0.001)$ reduction in the volume of paw edema at the $6^{\text {th }}$ hour following its administration. In case of anti-diarrheal activity a dose dependent reduction of fecal dropping was observed. Where the maximum reduction observed at the $2^{\text {nd }}$ hour at $500 \mathrm{mg} / \mathrm{kg}$ dose (68.42 \%) while the standard drug Loperamide produces $86.76 \%$ reduction of fecal dropping.

Conclusions: The findings of our study suggested that the methanol extract of Ixora cuneifolia possess a significant antioxidant, thrombolytic, analgesic, anti-inflammatory and anti-diarrheal activity.

Keywords: Ixora cuneifolia, Phytochemical, Antioxidant, Thrombolytic, Analgesic, Anti-Inflammatory, Anti-Diarrheal

\section{Background}

The tradition of using plants as herbal remedy for treating various disease conditions of human's dates back thousands of years [1]. The original sources of many important pharmaceuticals that are in current use are plants used by indigenous people. Some of the medicinal products currently in use were derived from plant sources and includes

\footnotetext{
* Correspondence: mariumpharm23@gmail.com

${ }^{7}$ Department of Pharmaceutical Technology, Faculty of Pharmacy, University of Dhaka, Dhaka 1000, Bangladesh

Full list of author information is available at the end of the article
}

anti-cancer drugs like vincristine, vinblastine and paclitaxel [2]; narcotic analgesics like morphine [3] as well as antimalarial drugs like quinine and artemisinin [4]. Even today a significant proportion of the population still relies on the traditional system of medicines to treat various diseases [5] and according to an estimation by the World Health Organization (WHO), around $80 \%$ of the world population still relies on drugs from plant sources [6].

Bangladesh is a good repository of medicinal plants and there are more than 500 different species of medicinal plants growing in Bangladesh of which around 250 
species are used for preparing traditional medicines [7]. Ixora cuneifolia an evergreen shrub belongs to the family Rubiaceae and is distributed throughout the regions of India, Bangladesh and other Southeast Asian countries [8]. In Bangladesh, the plant is known by the name of Musea and the leaves of this plant have been used in folk medicine for relieving fever and abdominal pains whereas the roots are used as antidiarrheal, antiemetic and for treating metorrhagia $[9,10]$.

To the best of our knowledge there are no published reports regarding the pharmacological activity of this plant to confirm its medicinal properties, as a result in our present study we investigated the antioxidant, thrombolytic, analgesic, anti-inflammatory and anti-diarrheal activities of the methanol extract of Ixora cuneifolia leaf.

\section{Methods}

\section{Chemicals}

Analytical grade reagents and chemicals were used in all the experimentations, procured from Merck (OriginGermany), unless mentioned otherwise. Diclofenac sodium, Tramadol and Loperamide hydrochloride were procured from Henan Dongtai Pharm Co., China.

\section{Collection of plant materials}

For the current investigation, the leaves of Ixora cuneifolia were collected from Bangladesh National Herbarium, Dhaka, Bangladesh during the month of September 2013. It was identified by the experts of the Bangladesh National Herbarium. (Accession number: 38343). The leaf part of the plant was collected and washed to separate the undesirable parts followed by drying at room temperature for two days. After drying the leaves were grinded to make a coarse powder. The powder was then sieved by using a sieving machine and the fine powder was collected and weighed using an analytical balance. The powder material was then stored in an airtight container and kept in a cool environment before the start of the extraction process.

\section{Preparation of crude extract}

For the preparation of the crude extract, 450 gm of powdered material was obtained and taken in a clean, flatbottomed glass container and soaked in $1750 \mathrm{ml} 90 \%$ Methanol. The container was then sealed with an aluminum foil and kept for a period of 7 days accompanying occasional shaking and stirring. The whole mixture then underwent a coarse filtration by a piece of clean, white cotton material. Then it was filtered by using Whatman filter paper. After seven days the methanol extract was evaporated by means of a rotary evaporator (Bibby RE-200, Sterilin Ltd., UK) at 5-6 rpm and at $68{ }^{\circ} \mathrm{C}$ temperature to render a gummy dark green colored concentrate that was designated as the crude methanol extract of Ixora cuneifolia
(MEIL). Then the crude extract was dried in a freeze drier and preserved at $+4{ }^{\circ} \mathrm{C}$ for two weeks.

\section{Preliminary phytochemical screening}

The methanol extract of I. cuneifolia leaf was qualitatively analyzed for identifying the presence of compounds like tannins, flavonoids, saponins, alkaloids, terpenoids, gums, reducing sugars and steroids. The phytochemical screening was carried out by known methods [11, 12].

\section{Free radical scavenging by DPPH method}

The free radical scavenging assay by DPPH method was conducted in accordance to the method described by Brand-William et al. [13] with minor modifications to determine the antioxidant activity MEIL. Ascorbic acid was used as the reference standard and was prepared in concentrations of 25,50,100,200, 400 and $800 \mu \mathrm{g} / \mathrm{ml}$. MEIL of concentrations 25, 50, 100, 200, 400 and $800 \mu \mathrm{g} / \mathrm{ml}$ were also prepared. $5 \mathrm{ml}$ of DPPH solution in $90 \%$ methanol was mixed with an equal volume of the extract and ascorbic acid. The resulting solution was kept in the dark for thirty minutes after which the absorbance was read at $517 \mathrm{~nm}$ by using a UV spectrophotometer. The degree to which the initial purple color of DPPH solution decolorizes to yellow indicates the free radical scavenging ability of the extract.

\section{Determination of total phenolic content}

The total phenolic content was determined by using Folin-Ciocalteu reagent according to the method of Singleton and Rossi [14]. $0.5 \mathrm{ml}$ of the plant extract of five different concentrations $(50,100,150,200$ and $250 \mu \mathrm{g} / \mathrm{ml}$ ) was mixed with Folin-Ciocalteu reagent and aqueous sodium carbonate. The mixture was then left for $15 \mathrm{~min}$ and the total amount of phenols were determined by using UV Spectrophotometry at $765 \mathrm{~nm}$. The total phenol in the extract was expressed as Gallic acid equivalents per gram of the plant extract.

\section{In vitro thrombolysis activity study}

The thrombolytic activity of the extract of was evaluated by the method developed by Daginawala [15] and slightly modified by Kawsar [16] using streptokinase (SK) as the standard. Commercially available lyophilized Altepase (Streptokinase) vial (Beacon pharmaceutical Ltd., Bangladesh) of 15,00,000 I.U. was collected and $5 \mathrm{ml}$ sterile distilled water was added and mixed properly. This suspension was used as a stock from which $100 \mu \mathrm{l}(30,000 \mathrm{I} . \mathrm{U})$ was used for in vitro thrombolysis. Blood $(n=5)$ was drawn from healthy human volunteers without a history of oral contraceptive or anticoagulant therapy and $1 \mathrm{ml}$ of blood was transferred to the previously weighed microcentrifuge tubes and was allowed to form clots. Three replicates of each sample were used 
for statistical analysis and the values were reported as mean $\pm \mathrm{SD}$.

\section{Test animals}

The animals were collected from International Centre for Diarrheal Disease and Research (ICDDR, B), Bangladesh. For the study of analgesic activity young Swiss-albino mice of either sex aged 4-5 weeks with an average weight of 22-30 g and for anti-inflammatory study young Swiss Long-Evans rats of either sex with an average weight of 125-145 g were divided into seven groups and maintained in the animal house at the North South University under standard environmental condition of temperature $\left(25^{\circ} \mathrm{C}\right)$ and light/dark cycles $(12 / 12 \mathrm{~h})$, acclimatized for 7 days before experiment. They were provided with standard food pellet and distilled water ad libitum. The Experiments were accomplished according to the guide for the care and use of laboratory animals. The protocols for conducting the experiments on the animals were approved by the institutional ethical committee [17].

\section{Acute toxicity study}

Overnight-fasted Swiss albino mice (20-35 g) of either sex were used for the study. The animals were divided into seven groups of five animals each having both sexes. Groups A to F received orally 250, 500, 1000, 2000, $3000,4000 \mathrm{mg} / \mathrm{kg}$ of the extract respectively, while the control (group G) received distilled water $(3 \mathrm{~mL} / \mathrm{kg}$ ) by the same route. General symptoms of toxicity and mortality in each group were observed within $24 \mathrm{~h}$. Animals that survived after $24 \mathrm{~h}$ were observed for any signs of delayed toxicity for two weeks.

\section{Hot plate test method}

Mice were divided into four groups (A-D) consisting of five animals in each group. The mice of each group were placed in the beaker (on the hot plate) which was maintained at a temperature of $54^{\circ} \pm 1{ }^{\circ} \mathrm{C}$ in order to obtain its response to electrical heat induced pain stimulus. Licking of the paws or jumping out of the beaker was taken as an indicator of the animal's response to heatinduced pain stimulus. Reaction time was denoted by the time (in seconds) it took for the mice to lick their paws or jump out of the beaker. The reaction time for the mice was taken once before the treatment was initiated. Mice of group A were treated with Distilled Water (Control), group B with Tramadol at a dose of $10 \mathrm{mg} / \mathrm{kg}$ of body weight (Positive Control) while group C and D were treated with methanol extract of Ixora cuneifolia at doses $250 \mathrm{mg} / \mathrm{kg}$ and $500 \mathrm{mg} / \mathrm{kg}$ body weight orally respectively. Thirty minutes after treatment, reaction time of the mice were taken once again and each time the mice licked their fore or hind paws or jumped out of the beaker was recorded. The recordings were made at an interval of $0,0.5,1,2,3$ and $4 \mathrm{~h}$ following oral administration of the samples [18-20]. Percent analgesic score (PAS) was calculated as

$$
(\mathrm{PAS})=\mathrm{Tb}-\mathrm{Ta} / \mathrm{Tb} \times 100
$$

Where, $\mathrm{Tb}=$ Reaction time (in second) before drug administration

$\mathrm{Ta}=$ Reaction time (in seconds) after drug administration

\section{Acetic acid induced writhing method}

The acetic acid induced writhing method to test analgesic activity was conducted according to the technique described by Siegmund et al. [21] and which was modified by Koster et al. [22].0.7 \% v/v Acetic acid solution at $10 \mathrm{~mL} / \mathrm{kg}$ body weight is administered intraperitoneally to the experimental animals to create pain sensation. As a positive control, Diclofenac Sodium was used to serve the purpose. The plant extract was administered orally in two different doses ( 250 and $500 \mathrm{mg} / \mathrm{kg}$ body weight) to the Swiss Albino mice after an overnight fast. Test samples and vehicle were administered orally $30 \mathrm{~min}$ prior to intraperitoneal administration of Acetic acid solution. Animals were kept individually under glass jar for observation. Each mouse of all groups were observed individually for counting the number of writhing they made in $10 \mathrm{~min}$ commencing just 5 min after the intraperitoneal administration of acetic acid solution.

The number of writhes in each treated group was compared to that of a control group (Distilled water) while Diclofenac Sodium (10 mg/kg) was used as a reference substance (positive control).

The percentage inhibition of the writhing was calculated by using the formula-

$$
\% \text { inhibition }=[(1-\mathrm{T}) / \mathrm{C}] \times 100
$$

Where, $\mathrm{C}=$ Mean number of writhing in control group

$\mathrm{T}=$ Mean number of writhing in test group.

\section{Carrageenan induced rat paw edema method}

The anti-inflammatory activity of MEIL was investigated by carrageenan induced inflammation in rat paw by following the method of Winter et al. [23] with minor modifications. Rats were randomly divided into four

Table 1 Results of phytochemical screening of methanol extracts of MEIL

\begin{tabular}{lllllllll}
\hline Extract & Tannin & Flavonoid & Saponin & Gum & Steroid & Alkaloid & Reducing Sugar \\
\hline MEIL & + & + & + & + & + & Terpenoid
\end{tabular}

MEIL: Methanol Extract of Ixora cuneifolia leaf. $+=$ Present, $-=$ Absent 


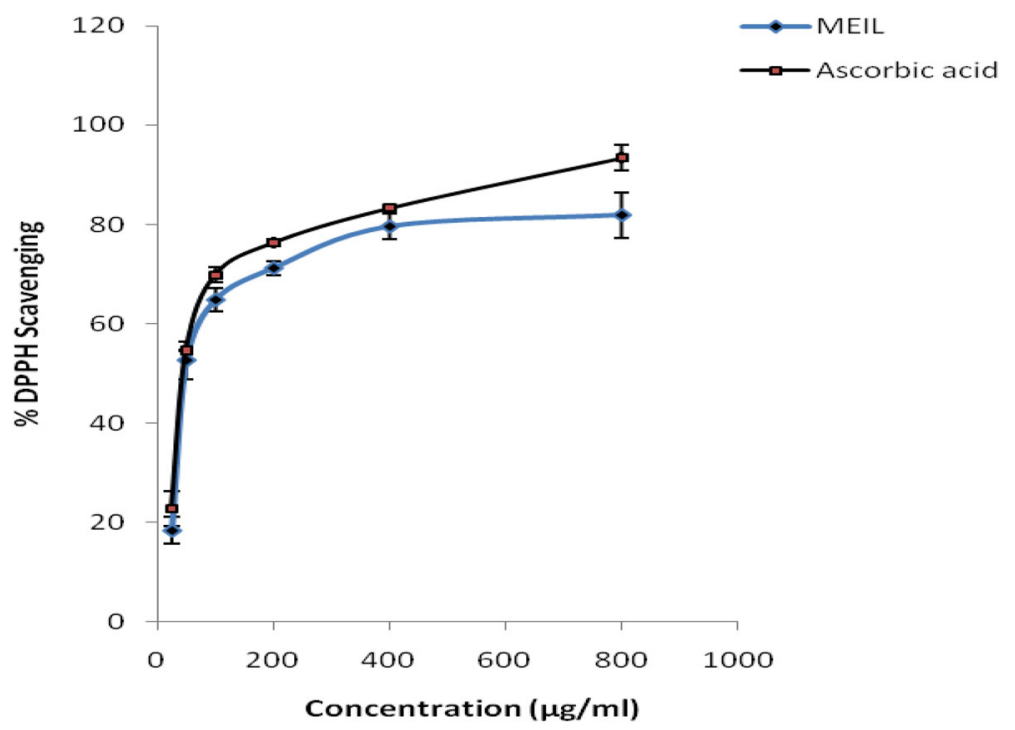

Fig. 1 DPPH radical scavenging activity of leaf methanolic extract of Ixora cuneifolia along with the standard Ascorbic acid. (Mean $\pm S D, n=3$ )

groups, each consisting of five animals, of which group I was kept as control giving only distilled water. Group II was given Diclofenac sodium $(10 \mathrm{mg} / \mathrm{kg})$ as standard. Group III and group IV were given the test sample at the dose of 250 and $500 \mathrm{mg} / \mathrm{kg}$ body weight respectively. Half an hour after the oral administration of the test materials, $1 \%$ carrageenan in saline was injected to the left hind paw of each rat. The volume of paw edema was measured at $0.5,1,3$ and $6 \mathrm{~h}$ using water plethysmometer after administration of carrageenan. The right hind paw served as a reference of non-inflamed paw for comparison.

The average percent increase in paw volume with time was calculated and compared against the control group. Percent inhibition was calculated using the formula-

$$
\% \text { Inhibition of paw edema }=\left[\left(\mathrm{V}_{\mathrm{c}}-\mathrm{V}_{\mathrm{t}}\right) / \mathrm{V}_{\mathrm{c}}\right] \times 100
$$

Where $V_{c}$ and $V_{t}$ represent average paw volume of control and treated animal respectively.

\section{Castor oil induced antidiarrheal method}

Castor oil-induced diarrhea was done according to the method of Soba et al. [24] and Uddin et al. [25] with simple modification. Rats of either sex were divided into four groups of five rats each. The animals were fasted for $18 \mathrm{~h}$

Table 2 Total Phenolic content of Methanol Extract of Ixora cuneifolia leaf

\begin{tabular}{lc}
\hline Extract & Total phenol content (in $\mathrm{mg} / \mathrm{gm}$, Gallic acid equivalents) \\
\hline MEIL & $46.44 \pm 1.022$
\end{tabular}

MEIL: Methanol Extract of Ixora cuneifolia leaf. Values are the average of triplicate experiments and represented as mean \pm SD prior to the test. Group I was treated with normal saline ( $2 \mathrm{~mL} / \mathrm{kg}$ ), which served as control; while Group II received Loperamide $(10 \mathrm{mg} / \mathrm{kg})$. Groups III and IV received leaf methanol extracts $250 \mathrm{mg} / \mathrm{kg}$ and $500 \mathrm{mg} / \mathrm{kg}$ respectively. All doses were administered orally. After $1 \mathrm{~h}$, all groups received $1 \mathrm{~mL}$ of castor oil orally. Then animals were placed in cages lined with adsorbent papers and observed for $4 \mathrm{~h}$ for the presence of diarrhea defined as watery (wet), unformed stool. The control group result was considered as $100 \%$. The activity of each group was expressed as percent inhibition (\%) of diarrhea. The percent inhibition of defecation was calculated as follows:

$$
\% \text { Inhibition of defecation }=[(\mathrm{A}-\mathrm{B}) / \mathrm{A}] \times 100
$$

Where A indicated mean number of defecation caused by castor oil; $B$ indicated mean number of defecation caused by drug or extract.

\section{Statistical analysis}

The results of statistical analysis for the experiments were expressed as the mean \pm SEM and were evaluated by one way analysis of variance (ANOVA) followed by Dunnet's multiple comparisons. The results obtained were compared with the vehicle control group. The $p$ values $<0.05$ was considered to be statistically significant. All statistical tests were carried out using SPSS (17.0 version) statistical software.

\section{Results and discussion}

\section{Phytochemical screening}

The results obtained from phytochemical screening of MEIL are presented in Table 1 . The results from the phytochemical screening revealed the presence of 


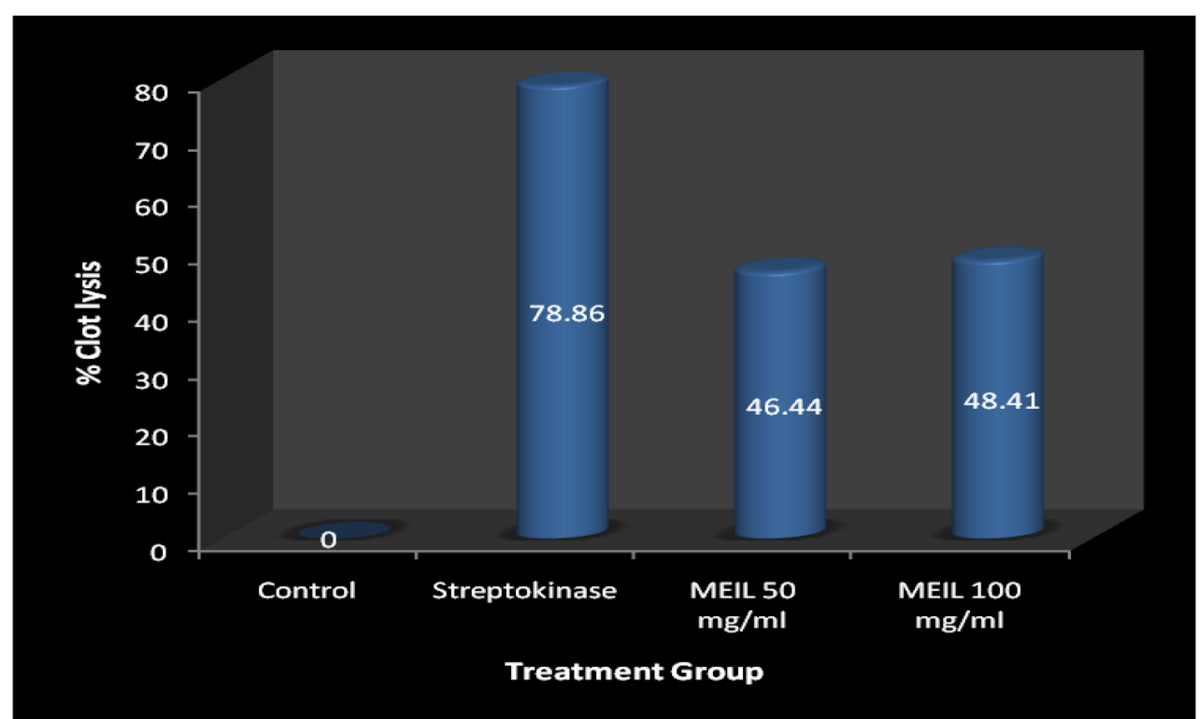

Fig. 2 Percentage of clot lysis activity of methanolic extract of Ixora cuneifolia leaf along with the standard Streptokinase. $($ Mean $\pm S D, n=3)$

tannins, flavonoids, saponins, terpenoids, gums, reducing sugars and steroids.

\section{Antioxidant activity}

\section{Free radical scavenging by DPPH method}

The free radical scavenging of the extract by DPPH method is shown in Fig. 1. The radical scavenging activity of the extract was found to increase with increasing concentration of the plant extract; however the percentage scavenging activity was not equal to the standard ascorbic acid. The half maximal inhibitory concentration $\left(\mathrm{IC}_{50}\right)$ of the extract and the standard were determined and was found to be $5.38 \mu \mathrm{g} / \mathrm{ml}$ for ascorbic acid and $57.64 \mu \mathrm{g} / \mathrm{ml}$ for MEIL.

\section{Total phenolic content}

Total phenolic content of MEIL was determined by using the Folin-Ciocalteu reagent and was expressed as Gallic acid equivalents (GAE) in milligrams per gram of plant extract. The total phenolic contents of the test fractions were calculated using the standard curve of Gallic acid ( $\left.y=0.3453 \times ; R^{2}=0.738\right)$. Methanol extract of Ixora cuneifolia was found to contain moderate amount of phenols (Table 2). The average phenol content of the extract was $46.44 \pm 1.022 \mathrm{mg}$ Gallic acid equivalent per gram of the plant extract.

\section{In vitro thrombolytic activity}

The observed thrombolytic activity showed potent effect of thrombolysis (48.41\%) of the tested extract as compared to standard streptokinase's clot lysis (78.86 \%) activity (Fig. 2). The percentage (\%) of clot lysis was significant $(P<0.01)$ when compared with control. This might be an important finding which might have important implications in cardiovascular health.

\section{Analgesic activity Hot plate test method}

The result of the hot plate test of MEIL is presented in Table 3. The extract significantly $(\mathrm{p}<0.05-0.001)$ increased the latency time of the thermal nociception in a dose dependent manner. The maximum effect of MEIL was observed at the $3^{\text {rd }}$ hour and the percentage of pain inhibition during this time at the dose of $500 \mathrm{mg} / \mathrm{kg}$ body weight of the extract $(72.81 \%)$ was comparable to the standard drug Tramadol (74.61\%).

Table 3 Analgesic activity of MEIL by hot plate method

\begin{tabular}{llllll}
\hline Group & \multicolumn{4}{l}{ Reaction time at different time intervals (in seconds) } & \\
\cline { 2 - 6 } & O Hour & $1^{\text {st }}$ Hour & $2^{\text {nd }}$ Hour & $3^{\text {rd }}$ Hour & $4^{\text {th }}$ Hour \\
\hline Control & $10.70 \pm 1.893$ & $8.00 \pm 1.820$ & $6.58 \pm 1.432$ & $5.52 \pm 1.227$ & $5.00 \pm 0.989$ \\
Standard (Tramadol) & $9.14 \pm 1.171$ & $12.60 \pm 2.113^{* *}(37.85)$ & $14.16 \pm 2.406^{* * *}(54.92)$ & $15.96 \pm 1.512^{* * *}(74.61)$ & $12.48 \pm 1.561^{* * *}(36.54)$ \\
MEIL $(250 \mathrm{mg} / \mathrm{kg})$ & $9.08 \pm 0.535$ & $12.18 \pm 0.570^{* *}(33.36)$ & $13.64 \pm 0.404^{* * *}(50.20)$ & $14.14 \pm 0.583^{* * *}(55.73)$ & $12.34 \pm 0.282^{* * *}(35.90)$ \\
MEIL $(500 \mathrm{mg} / \mathrm{kg})$ & $8.54 \pm 0.587$ & $10.96 \pm 0.758^{*}(28.34)$ & $12.88 \pm 0.505^{* * *}(50.80)$ & $14.76 \pm 0.592^{* * *}(72.81)$ & $11.76 \pm 0.704^{* * *}(37.89)$ \\
\hline
\end{tabular}

MEIL: Methanol Extract of Ixora cuneifolia leaf, Values in the table are expressed as mean \pm SEM, $(n=5)$. Values in parenthesis indicates percentage inhibition ${ }^{*} P<0.05,{ }^{* *} P<0.01,{ }^{* * *} P<0.001$ were considered statistically significant in comparison with control 
Table 4 Analgesic activity study of the methanolic extract of MEIL by acetic acid induced writhing method

\begin{tabular}{lcl}
\hline Treatment & Number of writhing's & $\%$ Inhibition \\
\hline Control & $26.60 \pm 1.07$ & - \\
Standard (Diclofenac Sodium) & $4.00 \pm 0.31^{* * *}$ & $84 \%$ \\
MEIL (250 mg/kg) & $11.00 \pm 2.73^{* * *}$ & $58 \%$ \\
MEIL (500 mg/kg) & $8.80 \pm 1.46^{* * *}$ & $66 \%$ \\
\hline
\end{tabular}

SEM $=$ Standard error of mean, $n=5, \%=$ percentage. Values in the table are expressed as mean \pm SEM, ${ }^{* * *} P<0.001$ was considered statistically significant in comparison with control

\section{Acetic acid induced writhing method}

The results of acetic acid induced writhing method are presented in Table 4. The extract caused significant depletion $(p<0.001)$ of the number of writhing induced by acetic acid in mice in a dose dependent manner. Highest inhibition of writhing was found at a dose of $500 \mathrm{mg} / \mathrm{kg}$ (66\%); however the percentage inhibition was not equal but comparable to the standard NSAID Diclofenac sodium (84\%).

\section{Anti-inflammatory activity Carrageenan induced rat paw edema}

The result of the anti-inflammatory activity of MEIL is illustrated in Table 5 and the changes in the rat paw volume over time by the extract and the standard drug is given in Fig. 3. MEIL displayed anti-inflammatory activity in a dose dependent manner. Both doses of the extract showed significant $(p<0.001)$ activity at $6^{\text {th }}$ hour after carrageenan administration (\% inhibition were $42.01 \%$ \& $44.97 \%$ for $250 \mathrm{mg} / \mathrm{kg}$ and $500 \mathrm{mg} / \mathrm{kg}$ dose respectively). Positive control Diclofenac sodium showed greater anti-inflammatory activity (49.70\%) than the extract.

\section{Anti-diarrheal activity}

\section{Castor oil induced method}

In castor oil induced diarrhea test, the extract showed considerable antidiarrheal effect in mice. The extract significantly inhibited the frequency of defecation when compared with untreated control group $(p<$ 0.05). In case of anti-diarrheal activity a dose dependent reduction of fecal dropping was observed. Where the maximum reduction observed at the $2^{\text {nd }}$ hour at $500 \mathrm{mg} / \mathrm{kg}$ dose (68.42\%) while the standard drug Loperamide $(10 \mathrm{mg} / \mathrm{kg})$ produces $86.76 \%$ reduction of fecal dropping. The results are shown in Tables 6 and 7.

\section{Discussion}

In our current study the antioxidant, thrombolytic, analgesic, anti-inflammatory and antidiarrheal properties of the methanol extract of Ixora cuneifolia leaves was determined and the results of our study clearly portrays significant antioxidant, thrombolytic, analgesic, anti-inflammatory and antidiarrheal properties. Initial phytochemical screening revealed the presence of phytocompounds like tannins, flavonoids, saponins, gums, steroids, reducing sugars and terpenoids. The analgesic and anti-inflammatory activities exhibited by the extract may be due to the presence of polyphenolic compounds like flavonoids and tannins [26, 27]. These polyphenolic compounds may also be responsible for the antioxidant activity $[28,29]$. The presence of saponins may play a role in the observed anti-inflammatory and antioxidant activities [30, 31].

The antioxidant activity of $I$. cuneifolia was demonstrated by using DPPH free radical scavenging and total phenolic content methods. The presence of $\mathrm{O}_{2}$ free radical can bring about a number of changes in the human body like initiation of lipid peroxidation which will lead to altered structure and function of collagen basement membranes that plays role in diabetic complications [32]. The extract exhibited significant free radical scavenging properties. The total phenolic content of the extract was determined by using Folin Ciocalteu reagent and the results were expressed as Gallic acid equivalent. The antioxidant activity of plants can be attributed to the presence of phenols which acts as free radical scavengers [33]. The radical scavenging activity of phenols is due to the presence of hydroxyl group in their aromatic structure [34]. The presence of phenols and the radical scavenging property of the extract purport it to be a potential antioxidant.

Numerous research works have been conducted to discover the plants and natural food sources and their supplements having antithrombotic (anticoagulant and antiplatelet) effect and there is indication that consuming such food leads to prevention of coronary events and stroke [35-38]. As it is reported that stimulated platelets form platelets to platelets bonds, binds also to

Table 5 Anti-inflammatory effect of MEIL by Carrageenan induced paw edema in rats

\begin{tabular}{|c|c|c|c|c|c|c|}
\hline Treatment & 0 Hour & $1^{\text {st }}$ Hour & $2^{\text {nd }}$ Hour & $3^{\text {rd }}$ Hour & $6^{\text {th }}$ Hour & $\%$ Inhibition in $6^{\text {th }}$ Hour \\
\hline Control & $0.79 \pm 0.035$ & $1.31 \pm 0.193$ & $1.58 \pm 0.017$ & $1.78 \pm 0.034$ & $1.69 \pm 0.02$ & -— \\
\hline Diclofenac Sodium & $0.76 \pm 0.049$ & $0.962 \pm 0.051$ & $1.34 \pm 0.049$ & $1.08 \pm 0.047$ & $0.85 \pm 0.056^{* * *}$ & 49.70 \\
\hline MEIL (250 mg/kg) & $0.73 \pm 0.045$ & $1.15 \pm 0.015$ & $1.41 \pm 0.065$ & $1.18 \pm 0.091$ & $0.98 \pm 0.073^{* * *}$ & 42.01 \\
\hline MEIL (500 mg/kg) & $0.78 \pm 0.057$ & $1.12 \pm 0.058$ & $1.38 \pm 0.072$ & $1.12 \pm 0.10$ & $0.93 \pm 0.058^{* * *}$ & 44.97 \\
\hline
\end{tabular}

MEIL: Methanol Extract of Ixora cuneifolia leaf. Values in the table are expressed as mean \pm SEM, ${ }^{* * *} P<0.001$ was considered statistically significant in comparison with control 


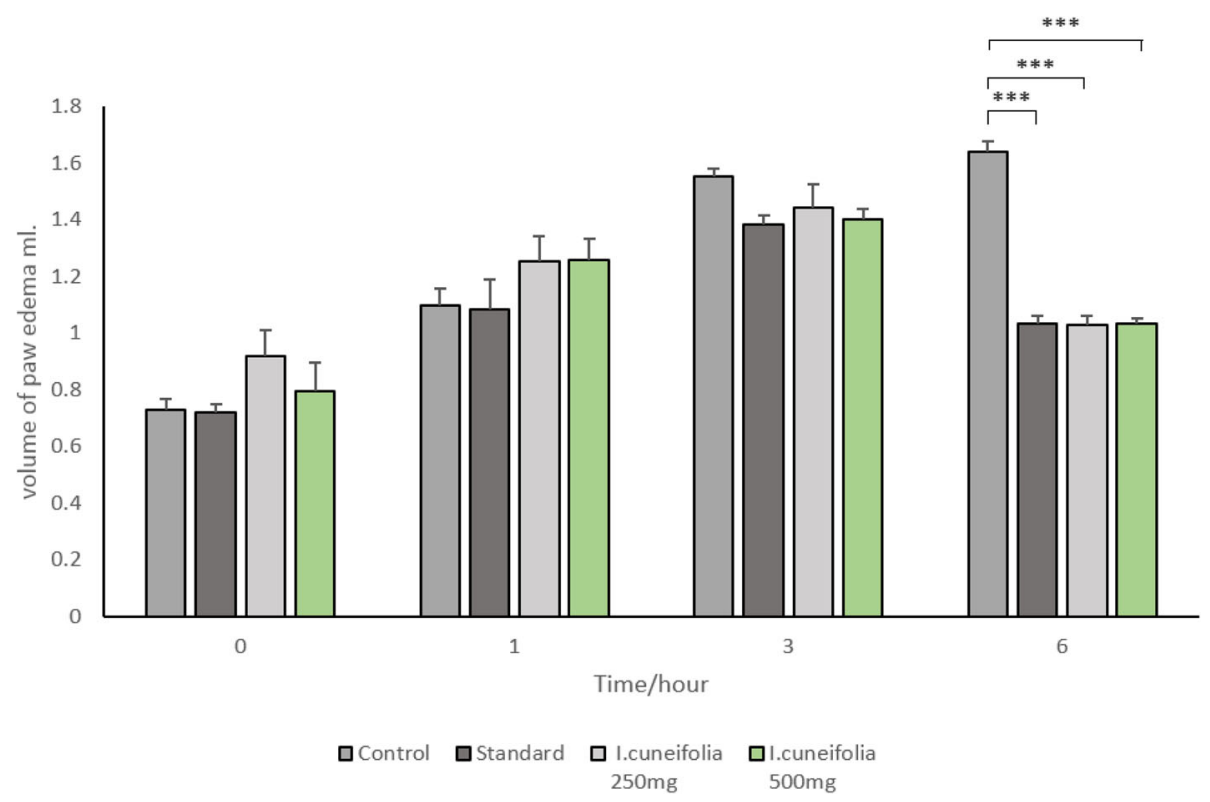

Fig. 3 Changes in paw volume in rats over time following Carrageenan induced edema

leucocytes carrying them into an intricate process of plaque development and progression [39], Plasmin, a natural fibrinolytic agent, lyses clot by breaking down the fibrinogen and fibrin contained in a clot. Preliminary phytochemical studies reveal that the extract might possesses tannin, saponin which could be participated for its clot lysis activity.

Two tests were employed for assessing analgesic activity, hot plate test for central analgesic activity and acetic acid induced writhing for peripheral analgesic activity. The hot plate method is an established method for determining central analgesic activity [40]. The established hot plate method is considered to be selective to examine compounds acting through opioid receptor [41]. It is usually used to screen narcotic analgesic. Although hot-plate test is commonly utilized to evaluate narcotic analgesic, other centrally acting drugs including muscle relaxants and sedatives have also been shown activity in this test [42]. However, indomethacin and other NSAIDs have no effect according to the hot-plate test $[43,44]$.
The tested extract showed a significant $(p<0.05)$ dose dependent reduction of pain from thermal stimuli at doses of 250 and $500 \mathrm{mg} / \mathrm{kg}$. The acetic acid induced writhing is the recommended protocol for evaluating peripheral analgesic activity of medicinal plants. Intraperitoneal administration of acetic acid causes an increase in the level of prostaglandins specially PGE2 and PGF2 $\alpha$ [45], lipooxygenase products [46], acetylcholine [47] and histamine [48] in the peritoneal fluids. These endogenous products results in pain and inflammation and as the extract inhibited the number of writhing, it might be correlated with its analgesic activity by the inhibition of the pain mediators. As our plant extract is inhibiting pain of both central and peripheral origin it can be suggested that they might be acting through both central and peripheral mechanisms.

Carrageenan induced edema is one of the most classical and extensively used method for studying acute inflammation [49]. The administration of the phlogistic agent results in the synthesis or release of mediators which includes prostaglandins, histamine, bradykinins and leukotrienes at the site of injury [50,51]. Inhibiting

Table 6 Weight of feces at different time interval

\begin{tabular}{llccc}
\hline Group/ Treatment & Dose & Weight of feces & Weight of feces & $\begin{array}{l}\text { Weight of feces } \\
\text { Third hour (gm) }\end{array}$ \\
\hline Control (Castor oil) & $0.4 \mathrm{ml}$ & $0.79 \pm 0.03$ & $0.76 \pm 0.04$ & $0.88 \pm 0.04$ \\
Standard (Loperamide) & $10 \mathrm{mg} / \mathrm{kg}$ & $0.13 \pm 0.06^{* *}$ & $0.1 \pm 0.04^{* * *}$ & $0.16 \pm 0.09^{* * *}$ \\
MEIL & $250 \mathrm{mg} / \mathrm{kg}$ & $0.35 \pm 0.03$ & $0.30 \pm 0.04$ & $0.38 \pm 0.06^{*}$ \\
MEIL & $500 \mathrm{mg} / \mathrm{kg}$ & $0.29 \pm 0.01$ & $0.24 \pm 0.01^{*}$ & $0.31 \pm 0.02^{*}$ \\
\hline
\end{tabular}

MEIL: Methanol Extract of Ixora cuneifolia leaf. Values in the table are expressed as mean $\pm \mathrm{SEM},{ }^{*} P<0.05,{ }^{* *} P<0.01,{ }^{* * *} P<0.001$ significantly different in comparison with control 
Table 7 Percentage of fecal inhibition at different time interval

\begin{tabular}{lllll}
\hline Group/Treatment & Dose & $\begin{array}{l}\text { \% inhibition } \\
\text { of wet feces inhibition } \\
\text { (1st hour) }\end{array}$ & $\begin{array}{l}\text { \% inhibition } \\
\text { of wet feces } \\
\text { (2d hour) }\end{array}$ & $\begin{array}{l}\text { of wet feces } \\
\left(3^{\text {rd }} \text { hour }\right)\end{array}$ \\
\hline $\begin{array}{l}\text { Control } \\
\text { (Castor oil) }\end{array}$ & $0.4 \mathrm{ml}$ & - & - & - \\
$\begin{array}{l}\text { Standard } \\
\text { (Loperamide) }\end{array}$ & $10 \mathrm{mg} / \mathrm{kg}$ & 83.54 & 86.76 & 81.82 \\
MEIL & $250 \mathrm{mg} / \mathrm{kg}$ & 55.69 & 60.52 & 56.81 \\
MEIL & $500 \mathrm{mg} / \mathrm{kg}$ & 63.29 & 68.42 & 64.77 \\
\hline
\end{tabular}

the release of mediators at the injured site will minimize inflammation and any other symptoms associated with it. This model of acute inflammation is biphasic. The early phase $(0-2 \mathrm{~h})$ is initiated by the release of histamine, bradykinin, leukotrienes and serotonin by the damaged tissue surroundings. The late phase $(2-6 \mathrm{~h})$ is associated with the production of prostaglandins and reactive species like hydrogen peroxide and superoxide radical by the tissue macrophages $[52,53]$. The results from our study indicates Ixora cuneifolia shows significant anti edematic activity till the sixth hour of the administration of the phlogistic agent possibly by interfering with the production of prostaglandins at the damaged tissue surroundings.

Diarrhea is usually considered a result of altered motility and fluid accumulation within the intestinal tract. Recent study claims that nitric oxide in castor oil is responsible for the diarrheal effect, although it is evidenced that ricinoleic acid produces diarrhea through a hypersecretory response which is the most active component of castor oil [54, 55].

There are several mechanisms proposed to explain the diarrheal effect of castor oil including inhibition of intestinal $\mathrm{Na}+\mathrm{K}+$ ATPase activity, consequently reducing normal fluid absorption $[56,57]$, activation of adenylate cyclase or mucosal cAMP-mediated active secretion [58] and stimulation of prostaglandin formation and platelet activating factor [59]. Current study reveals the dose dependent activity of the extract. It was reported that flavonoids and polyphenols were responsible for the anti-diarrheal activities [60]. The presence of tannin, flavonoids in the phytochemical screening test might be responsible for the effect of the extract.

\section{Conclusions}

Based on our preliminary investigations it can be concluded that the methanolic extract of Ixora cuneifolia leaf displays significant antioxidant, thrombolytic, analgesic, anti-inflammatory and anti-diarrheal properties. Nevertheless further investigations are required to find the active component of the extract and to confirm the possible mechanism of action for developing a potent medicinal agent.

\section{Acknowledgement}

The authors would like to express their gratitude to Mr. Fakhar Uddin Majumder, Laboratory Officer Department of Pharmaceutical Sciences, North South University for his support during the period of the study.

\section{Authors' contributions}

$\mathrm{TBH}, \mathrm{AS}, \mathrm{TM}, \mathrm{MD}$ and MWR participated in the conduction of the experiments. MMB, MSH and MSR made substantial contributions to conception design and conduction of research. Data interptetation and analysis were done by TBH, AS, MMB,TM, MWR, BCA and MR. MSH, MD, MAN and MSR participated in drafting the manuscript and TBH, AS, MMB, TB revised the manuscript critically for important intellectual content. MSR made the necessary corrections in the write up. MMB gave final approval for the submission of revised version. All authors read and approved the final manuscript.

\section{Competing interests}

Tamanna Binte Huq, M. Sohanur Rahman, M. Akhlatun Nure, Md Solayman Hossain, Abeer Sarwar, Azharul Islam, Munny Das, Md Emdadul Haque, Tasnia Malik, Md Wali Reza, Bikash Chandra Adhikary, Minhazur Rahman, Taslima Begum and Mst Marium Begum declare that they have no competing interests.

\section{Author details}

${ }^{1}$ Department of Pharmaceutical Sciences, North South University, Bashundhara, Baridhara, Dhaka 1229, Bangladesh. ²Department of Biochemistry and Molecular Biology, University of Rajshahi, Rajshahi 6205, Bangladesh. ${ }^{3}$ Department of Zoology, University of Rajshahi, Rajshahi 6205, Bangladesh. ${ }^{4}$ Department of Pharmacy, Jahangirnagar University, Savar, Dhaka 1342, Bangladesh. ${ }^{5}$ Department of Pharmacy, Dhaka International University, Banani, Dhaka 1213, Bangladesh. ${ }^{6}$ Department of Pharmacy, Primeasia University, Dhaka 1213, Bangladesh. ${ }^{7}$ Department of Pharmaceutical Technology, Faculty of Pharmacy, University of Dhaka, Dhaka 1000, Bangladesh.

Received: 4 July 2016 Accepted: 7 October 2016

Published online: 26 October 2016

References

1. Gurib-Fakim A. Medicinal Plants: traditions of yesterday and drugs of tomorrow. Mol Aspects Med. 2006;27:1-93.

2. Cragg GM, Newman DJ. Plants as a source of anti-cancer agents. J Ethnopharmacol. 2005;100:72-9.

3. Rates SMK. Plants as source of drugs. Toxicon. 2001;39:603-13.

4. Queiroz EF, Wolfender JL, Hostettmann K. Modern approaches in the search for new lead anti-parasite compounds for higher plants. Curr Drug Targets. 2009:10:202-11.

5. Pal SK, Shukla Y. Herbal Medicine: current status and the future. Asian Pac J Cancer Prev. 2003:4:281-88.

6. Lim MK, Sadarangani P, Chan HL, Heng JY. Complementary and alternative medicine use in multiracial Singapore. Comp Ther Med. 2005;13:16-24.

7. Uddin SJ, Grice ID, Tiralongo E. Cytotoxic effects of Bangladeshi medicinal plant extracts. Evid Based Complement Alternat Med. 2011; vol. 2011.doi:10. 1093/ecam/nep111.

8. Mouly A, Razafimandimbison SG, Khodabandeh A, Bremer B. Phylogeny and classification of the species-rich pantropical showy genus Ixora (RubiaceaeIxoreae) with indications of geographical monophyletic units and hybrids. Am J Bot. 2009;96:686-706.

9. MasumGazi ZH, Sharkar P, Abu NM, Mafizur RM, Mizanur RM. Medicinal plants used by Kabiraj of fourteen villages in Jhenaidah district, Bangladesh. Global J Res Med Plants Indigen Med. 2013;2:10-22.

10. Motaleb MA, Abdullah-Al-Mamun MM, Hossain MK, Alam MK, Sultana M. Herbal healing: an old practice for healthy living among Khumi, Marma and Tripura communities of Thanchi Upazila, Bangladesh. European J Med Plants. 2015;5:23-52

11. Harborne JB. Phytochemical Methods: A guide to modern techniques of plant analysis. 3rd ed. London: Chapman and Hall; 1998. p. 302.

12. Sazada S, Verma A, Rather AA, Jabeen F, Meghvansi MK. Preliminary phytochemical analysis of some important medicinal and aromatic plants. Adv Biol Res. 2009;3:18-9.

13. Brand-William W, Cuvelier ME, Berset C. Use of free radical method to evaluate antioxidant activity. Lebensm-Wiss-U-Technol. 1995;28:25-30. 
14. Singleton VL, Rossi JA. Calorimetry of total phenolics with phosphomolybdic phosphotungstic acid reagents. Am J EnolVitic. 1965;16:144-58.

15. Prasad S, Kashyap RS, Deopujari JY, Purohit HJ, Taori GM, Daginawala HF. Development of an in vitro model to study clot lysis activity of thrombolytic drugs. Thromb J. 2006;1:14.

16. Kawsar MH, Sikder MAA, Rana MS, Nimmi I, Rashid MA. Studies of thrombolytic, antioxidant and cytotoxic properties of two asteraceous plants of Bangladesh. Bangladesh Pharm J. 2011;2:103-06

17. Zimmermann M. Ethical guidelines for investigations of experimental pain in conscious animals. Pain. 1983;16:109-10.

18. Eddy NB, Leimbach D. Synthetic analgesic II Dithienyl butyl and dithenylbutylamines. J Pharmacol Exp Ther. 1953;107:385-93.

19. Kulkarni SK. Handbook of Experimental Pharmacology. 3rd ed. Delhi: Vallabh Prakashan; 1999. p. 117.

20. Toma W, Graciosa JS, Hiruma-Lima CA, Andrade FD, Vilegas W, Souza Brito AR. Evaluation of the analgesic and antidematogenic activities of Quassia amara barks extract. J Ethnopharmacol. 2003:85:19-23.

21. Siegmund E, Cadmus R, Lu G. A method for evaluating both non-narcotic and narcotic analgesics. Exp Biol Med. 1957:95:729-31.

22. Koster R, Anderson M, De Beer EJ. Acetic acid for analgesic screening. Fed Proceed. 1959:18:412-16.

23. Winter CA, Risley EA, Nuss GW. Carrageenan induced edema in hind paw of the rat as an assay for anti-inflammatory drugs. Proc Soc Exp Biol Med. 1962;111:544-47.

24. Shoba FG, Thomas M. Study of antidiarrhoeal activity of four medicinal plants in castor-oil induced diarrhoea. J Ethnopharmacol. 2001;1:73-6.

25. Uddin SJ, Sjilpi JA, Alam SM, Alamgir M, Rahman MT, Sarker SD. Antidiarrhoeal activity of the methanol extract of the barks of Xylocarpusmoluccensis in castor oil- and magnesium sulphate induced diarrhoea models in mice. J Ethnopharmacol. 2005;101:139-43.

26. Osadebe PO, Oyoke FBC. Anti-inflammatory effects of crude methanolic extract and fractions of Alchornea cordifolia leaves. J Ethnopharmacol. 2003;89:19-24.

27. Kupeli E, Yesilada E. Flavonoids with anti-inflammatory and antinociceptive activities from Cistus laurifolius $L$. leaves through bioassay guided procedures. J Ethnopharmacol. 2007;112:524-30.

28. Awika JM, Rooney LW, Wu X, Prior RL, Cisneros-Zevallos L. Screening methods to measure antioxidant activity of sorghum (Sorghum bicolor) and sorghum products. J Agric Food Chem. 2003:51:6657-62.

29. Kähkönen MP, Hopia Al, Vuorela HJ, Rauha JP, Pihlaja K, Kujala TS, et al. Antioxidant activity of plant extracts containing phenolic compounds. J Agric Food Chem. 1999;47:3954-62.

30. Sur P, Chaudhuri T, Vedasiromoni JR, Gomes A, Ganguly DK. Antiinflammatory and antioxidant property of saponins of tea [Cameliasinensis (L) O. kuntze] root extract. Phytother Res. 2001;15:174-76.

31. Li JP, Liang ZM, Yuan Z. Triterpenoid saponins and anti-inflammatory activity of Cadonopsis lancelota. Pharmazie. 2007:62:463-66.

32. Sabu MC, Kuttan R. Antidiabetic activity of medicinal plants and its relationship with their antioxidant property. J Ethnopharmacol. 2002;81:155-60.

33. Shukla S, Mehta A, John J, Singh S, Mehta P, Vyas SP. Antioxidant activity and total phenolic content of ethanolic extract of Caesalpinia bonducella seeds. Food Chem Toxicol. 2009;47:1848-51.

34. Villano D, Fernández-Pachón MS, Moyá ML, Troncoso AM, Garcia-Parrilla MC Radical scavenging ability of polyphenolic compounds towards DPPH free radical. Talanta. 2007;71:230-35.

35. Ratnasooriya WD, Fernando TSP, Madubashini PP. In vitro thrombolytic activity of Sri Lankan black tea, Camellia sinensis (L). Kuntze J Nat Sci Found. 2008:36:179-81.

36. Joshipura KJ, Ascherio A, Manson JE, Stampfer MJ, Rimm EB, Speizer FE, Hennekens $\mathrm{CH}$, Spiegelman D, Willett WC. Fruit and vegetable intake in relation to risk of ischemic stroke. JAMA. 1999;13:1233-9.

37. Liu S, Manson JE, Lee IM, Cole SR, Hennekens CH, Willett WC, Buring JE. Fruit and vegetable intake and risk of cardiovascular disease: the Women's Health Study. Am J Clin Nutr. 2000:4:922-8.

38. Bazzano LA, He J, Ogden LG, Loria CM, Vupputuri S, Myers L, Whelton PK. Fruit and vegetable intake and risk of cardiovascular disease in US adults: the first National Health and Nutrition Examination Survey Epidemiologic Follow-up Study. Am J Clin Nutr. 2002;1:93-9.

39. Prentice CRM. Platelets and Atherosclerosis. Eur Heart J Suppl. 1999;1:3-7.

40. Derardt R, Jogney S, Delvalcee F, Falhout M. Release of prostaglandins E and F in algogenic reaction and its inhibition. Eur J Pharmacol. 1980;51:17-24.
41. Pal S, Sen T, Chaudhuri AK. Neuropsychopharmacological profile of the methanolic fraction of Bryophyllumpinnatum leaf extract. J Pharm Pharmacol. 1999;51:313-8.

42. Eddy NB, Leimbach D. Synthetic analgesics. II. Dithienylbutenyl- and dithienylbutylamines. J Pharmacol Exp Ther. 1953;3:385-93.

43. Yamamoto T, Nozaki-Taguchi N. Analysis of the effects of cyclooxygenase (COX)-1 and COX-2 in spinal nociceptive transmission using indomethacin, a non-selective COX inhibitor, and NS-398, a COX-2 selective inhibitor. Brain Res. 1996;739:104-10.

44. Santos ARS, Vedana EMA, Freitas GAG. Antinociceptive effect of meloxicam, in neurogenic and inflammatory nociceptive models in mice. Inflamm Res. 1998;47:302-7

45. Sani YM, Musa AM, Pateh UU, Haruna AK, Yaro AH, Sani MB, et al. Phytochemical screening and preliminary evaluation of analgesic and antiinflammatory activities of the methanol root extract of Cissus polyantha. Bayero J Pure Appl Sci. 2014;7:19-23.

46. Muhammad N, Saeed M, Khan H. Antipyretic, analgesic and anti-inflammatory activity of Viola betonicifolia whole plant. BMC Comp Alt Med. 2012;12:59.

47. Alexandre-Moreira MS, Piuvezam MR, Araujo CC, Thomas G. Studies on the anti-inflammatory and analgesic activity of Curatella Americana L. J Ethnopharmacol. 1999;67:171-77.

48. Serafini MR, Santos RC, Guimaraes AG, dos-Santos JPA, da Conceicao Santos $A D$, Alves $\mid A$, et al. Morinda citrifolia Linn leaf extract possess antioxidant activities and reduces nociceptive behavior and leukocyte migration. J Med Food. 2011;14:1159-66.

49. Guay J, Bateman K, Gordon R, Mancini J, Riendeau D. Carrageenan-induced paw edema in rat elicits a predominant prostaglandin E2 (PGE2) response in the central nervous system associated with the induction of microsomal PGE2 synthase-1. J Biol Chem. 2004;279:24866-72.

50. Asongalem EA, Foyet HS, Ekabo S, Dimo T, Kamtchouing P. Antiinflammatory, lack of analgesic and antipyretic properties of Acanthus montanus (Ness) T Anderson. J Ethnopharmacol. 2004;95:63-8.

51. Kumar S, Kumar V, Prakash OM. Pharmacognostic study and antiinflammatory activity of Callistemon lanceolatus leaf. Asian Pac J Trop Biomed. 2011:1:177-81.

52. Gupta M, Mazumder UK, Gomathi P, Thamil SV. Anti-inflammatory evaluation of leaves of Plumeria acuminate. BMC Comp Alt Med. 2006:6:36.

53. Bignotto L, Rocha J, Sepodes B, Eduardo-Figueira M, Pinto R, Chaud M, et al. Anti-inflammatory effect of lycopene on carrageenan induced paw oedema and hepatic ischaemia in the rat. Br J Nutr. 2009;102:126-33.

54. RacusenL C, Binder HJ. Ricinoleic acid stimulation of active anion secretion in colonic mucosa of the rat. J Clin Invest. 1979:4·743-9.

55. Vieira C, Evangelista S, Cirillo R, Lippi A, Maggi CA, Manzini S. Effect of ricinoleic acid in acute and subchronic experimental models of inflammation,". Mediators Inflamm. 2000;5:223-8.

56. Capasso F, Mascolo N, Izzo AA, Gaginella TS. Dissociation of castor oilinduced diarrhoea and intestinal mucosal injury in rat: effect of $N(G)$-nitro- $L$ arginine methyl ester. Br J Pharmacol. 1994:4:1127-30.

57. Imam MZ, Sultana S, Akter S. Antinociceptive, antidiarrheal, and neuropharmacological activities of Barringtonia acutangula. Pharm Biol. 2012;9:1078-84.

58. Pinto A, Autore G, Mascolo N, Sorrentino R, Biondi A, Izzo AA, Capasso F. Time course of PAF formation by gastrointestinal tissue in rats after castor oil challenge. J Pharm Pharmacol. 1992;3:224-6.

59. Mascolo N, Izzo AA, Autore G, Barbato F, Capasso F. Nitric oxide and castor oil induced diarrhea. J Pharmacol Exp Ther. 1994;1:291-5.

60. Dosso K, N'quessan BB, Bidie AP, Gnangoran BN, Méité S, N'quessan D, Yapo AP, Ehilé EE. Antidiarrhoeal activity of an ethanol extract of the stem bark of Piliostigma reticulatum (Caesalpiniaceae) in rats. Afr J Tradit Complement Altern Med. 2012;2:242-9. 